\title{
Study on the Development of Ethnic Museums in China's Belt and Road Initiative
}

\author{
Jinghong Zhang \\ Yunnan Nationalities Museum, 1503\# Dianchi Road, Kunming City, Yunnan Province, China 650228
}

\begin{abstract}
Ethnic museums collect, research and protect tangible and intangible cultural heritage of 56 ethnic groups in China to fulfill their obligations of consolidating national identities. Under the context of national programme of Belt and Road Initiative, ethnic museums face both strategic opportunities and historical challenges. The paper clarifies ethnic museums' new positioning, defines their development goal and historical mission, analyzes new advantages of ethnic museums' geographic and cultural resources, and discusses from an international perspective on how ethnic museums innovate their working concepts, contents and models to become international radiation centers of ethnic cultures in cooperation with the Belt and Road Initiative.
\end{abstract}

Keywords: Ethnic museums, Development, Belt and Road Initiative, National strategy.

\section{Introduction}

Belt and Road Initiative follows a historical symbol of ancient Silk Road, inherits its open and inclusive spirits, and provides a regional cooperation framework for world politics, economy and culture. It is a brand-new reform and opening to the outside world in Chinese way, also a major measure to expand and deepen the development of China and neighbouring countries. With the opportunities rising from new round of reform and opening up, ethnic museums need analyze their positioning and advantages in the Belt and Road Initiative, clarify their development direction. By taking their emerging advantages, ethnic museums try to become cultural centers, contribute to a parallel development between economy and culture in the Belt and Road Initiative in order to achieve dual goals of economic cooperation and cultural development, and establish an international status of culture equivalent to China's economic momentum.

\section{Analysis of New Positioning for Ethnic Museums in The Belt and Road Initiative}

Belt and Road Initiative is China's new pattern of opening up to cope with ever-changing international and domestic situations. It tries to handle bilateral/multilateral international relations with a concept of development, which brings important strategic development opportunities while creating a new model of regional cooperation. Since the implementation of the Belt and Road Initiative, social economy and culture at home and abroad have undergone unprecedented changes and development, so as to the status and influence of museums. From an international perspective, ethnic museums should re-examine their positioning and geographical advantages, recognize their development path and historical \& cultural mission, actively promote the implementation of Belt and Road Initiative.

Museum undertaking has been upgraded to a national strategy, participating in the implementation of Belt and Road Initiative. Since the People's Republic of China was founded, the museum cause has made considerable progress. The state has discussed and revised the definition of museum several times. In 1979, the National Symposium on Museum Work stipulated for the first time through Museum Work
Regulations of Provinces, Municipalities and Autonomous Regions: Museums are main institutions of collection, publicity \& education and scientific research of cultural relics and specimens, and an important part of China's scientific and cultural undertaking. Since then, Museum Regulations that have been revised and passed all focus on basic duties, functions and roles of museums, clarified the status of museums as an important social education infrastructure of the country. In November 2016, Vice Premier Liu Yandong of State Council read a congratulatory letter from President Xi Jinping at UNESCO High Level Forum on Museums and delivered an important speech: Chinese government attaches great importance to the cause of museums and elevates it as a national cultural strategy. Each country faces a common task to build, protect and make good use of museums[1]. Through this forum, Chinese government for the first time has made it clear to the international communities that museums possess a strategic height. The construction and development of museums are listed as an important task for China, and the status of museums has undergone essential changes along with national development programme. Museums have now risen from basic cultural and educational facilities to national cultural strategy.

Belt and Road Initiative has changed traditional location disadvantages of ethnic museums into new geographical advantages. Most existing China's ethnic museums locate in frontier minority areas along borderlines, remote politically, economically and culturally without any advantages of locations. The Belt and Road Initiative connects countries and regions along the route, forms multiple centers extending in all directions. Frontier regions are no longer the periphery because they are far away from the state center. Former frontiers have become the present and future strategic front lines. All frontier regions have gradually awakened to the development opportunities brought by the implementation of Belt and Road Initiative, and the development of frontiers is no longer limited by geographic locations[2]. Former frontiers are now becoming the "central areas" of politics, economy and culture, and moving from "national borders" to "national strategic centers". The Belt and Road Initiative ushered an era of "centralization of frontiers", which has unprecedentedly reversed previous remote locations of ethnic museums in frontier regions and obtained new central 
geo-coordinates. Museums in ethnic regions should also seize development opportunities of the national strategic plan, recognize the changes in geographic location from the frontier to the center, transcend the limitations of geographic space in consciousness, break through traditional development paths for a purpose of cross-regional development.

Development direction of ethnic museums in the Belt and Road Initiative is to build international ethnic cultural radiation centers. The Belt and Road Initiative takes a lead in building economic and cultural radiation centers, which plays a very important role to enhance understanding and mutual trust between China and countries along the route, as well as form a community of responsibilities and interests. Single cultural institutions or cultural centers composed of museums can no longer satisfy people's growing spiritual and cultural life. Constructing comprehensive and diversified cultural centers is a main goal to enhance the soft power of regional culture and promoting cultural development and prosperity. Tremendous influence, radiation and penetration of ethnic culture will enrich and benefit spiritual life of people along the Belt and Road Initiative countries, and expand the radiation radius of Chinese ethnic culture. Construction of ethnic cultural radiation centers is a process not only to build a new regional cultural pattern, but also to explore and discover cultural development trends and advantages, which is conducive to understanding and overcoming various difficulties and constraints might face in economic construction and development. China and neighbor countries ultimately will realize common economic and cultural development and prosperity[3].

In the Belt and Road Initiative, ethnic museums shoulder a historical mission to consolidate national identity internally and enhance cultural confidence externally. As global cultural facilities, museums assume an important historical mission for international communities to record and maintain cultural diversity as centers of world culture and hubs for dialogue. Tangible and intangible cultural heritage collected by museums retain social and cultural history of human beings, which are platforms to enjoy and learn concepts and values of cultural heritage, to inherit advanced and excellent spiritual culture of various countries, to promote exchanges between different cultures and enhance respect and understanding of ethnic cultures. As national non-profit cultural institutions, ethnic museums serve national cultural strategies under the framework of the Belt and Road Initiative, and always keep a dominant position of national culture in the trend of global integration. With the collection of national cultural evidence, ethnic museums display the connotation and extension of national culture to deepen the understanding on national culture in ever-changing cultural trends, condense and strengthen cultural identities of Chinese nation, stimulate a driving force of national culture, and shoulder a historical responsibility to inherit Chinese traditional culture.

\section{Advantages of Ethnic Museums in The Belt and Road Initiative}

Ethnic museums are the main carrier of national culture, an important member of museum system, and a key component of cultural relics and museum work. They record spiritual wealth of different ethnic cultures and possess unique advantages to conduct dialogues and cultural exchanges among different cultures, different ethnic groups and different generations. Thereby ethnic museums protect the diversities of ethnic cultures.

Ethnic museums are a business card of China's pluralism. Ethnic museums are dedicated to collecting, protecting, researching and promoting the outstanding cultural heritage of 56 ethnic groups. They are a vital part of Chinese cultural undertaking system and presents cultural diversities of China to the world in a vivid and unique way. Ethnic museums have created a national identity for China as a pluralistic unity. They are places where ethnic cultures converge and ethnic memories inherit, intuitively and quickly reflecting specific national conditions of China's multi-ethnic groups. Ethnic museums embody national ethnic policies of "All ethnic groups unite and strive together for common prosperity and development", maintain the unity \& integrity, the progress \& unity of the nation as well. Ethnic museums are the key unit to protect the nation's outstanding traditional cultural heritage, which are precious cultural resources to build harmonious society and rejuvenate Chinese culture, also vivid teaching materials to cultivate the national spirit and promote excellent ethnic culture of China.

Ethnic museums are new outlets of Chinese culture under the Belt and Road Initiative. They collect precious cultural relics of various ethnic groups, records production and life tracks of ethnic groups, embody wisdom of working people of ethnic groups, which carry historical \& humanistic value, aesthetic value and educational experience value. As symbolic public facilities of national culture and overall image window, ethnic museums bridge the history and the present, connect regional cultural resources of various countries in the space. They can not only spread national culture through exhibits, but also export national cultural products to audience as new cultural outlets, vividly display cultural characteristics and profound cultural heritage of China. As new outlet windows, ethnic museums disseminate and output Chinese culture, exchange and integrate values of various nationalities, enhance friendship and overcome differences, gain understanding on Chinese culture among countries and nationalities along the Belt and Road Initiative.

Ethnic museums have advantages to bridge public cultures along the Belt and Road Initiative. The Belt and Road Initiative involves 31 domestic provinces, autonomous regions and municipalities of China. As of 30 January 2021, China has signed cooperation documents with 140 countries and 31 international organizations on the Belt and Road Initiative[4]. The initiative covers different countries, cultures and religious beliefs. Many countries locate where eastern and western civilizations converge with diverse national cultures \& customs, and ideological differences[5]. Ethnic, religious and racial issues are prominent there, and relations are complex between countries along the route. Negative factors and difficulties might merge to affect the cooperation process and effectiveness of Belt and Road Initiative. Ethnic museums of different countries and regions can find resonance as entry point in traditional ethnic culture and art and explore the best way to cooperate with their 
advantages in history, culture and geography. They conduct extensive cultural exchanges in order to deepen cooperation between countries by exchanging thoughts \& ideas, promote mutual understanding and peaceful coexistence among peoples of all countries, so as to develop economic and trade exchanges in a long term.

Ethnic museum system has a scale advantage for cultural exchanges. Since the reform and opening up, China's museum cause has shown a strong momentum of development. When the People's Republic of China was founded in 1949, there were only 21 museums left over. At the end of 2019, there were 5,535 registered museums nationwide, 263 times the number of 1949. 28,600 exhibitions and 334,600 educational activities were held which received 1.227 billion visitors in 2019 alone[6]. Among them, there are nearly 400 ethnic museums, and more than 20 ethnic minorities have their own ethnic or folk museums. 12 western provinces and regions[7] where ethnic minorities live compactly in owns more than 500 museums; 30 ethnic autonomous prefectures and most of 120 autonomous counties have ethnic museums[8]. Yunnan, Guizhou, and Guangxi provinces have a dozen of ecological museums, which conduct beneficial explorations to the development of museums in western ethnic regions. Ethnic museums have formed an architecture community with a solid layout and systematization. They specialize in collecting, displaying and researching ethnic cultural heritage with complete functions, provide audiences with services such as knowledge, education and appreciation, and contribute realistic conditions to promote cultural exchanges along the Belt and Road Initiative.

\section{Problems and Disadvantages Faced by Ethnic Museums in The Belt and Road Initiative}

Although ethnic museums have the advantages of natural ethnic cultural resources, they still face many practical difficulties in the implementation process of Belt and Road Initiative, even encounter some disadvantages in the short term. Ethnic museums should have a clear understanding of their own weaknesses, carefully analyze and study these weaknesses, and take countermeasures to maximize strengths and avoid weaknesses, reverse and make up for shortcomings in order to achieve a long-term development.

Ethnic museums have insufficient understanding of their important strategic position. Unaware of overall situation, ethnic museums often arranges work with partial thoughts. They had long positioned themselves as infrastructure for collecting, protecting and promoting national culture, unable to accurately figure out their important strategic position in the state's political, economic, cultural and social development. With the implementation of Belt and Road Initiative, the development and changes require ethnic museums to recognize their strategic position, timely adjust their working patterns and thoughts, enhance their domestic and international status, and assume more national and social responsibilities to strengthen international influence of
Chinese culture.

Ethnic museum lacks forward-looking planning of development goals. Confined to their knowledge, most ethnic museums have been dedicated to showcasing characteristic culture of local ethnic groups, lacking a sense of long-term development direction under the Belt and Road Initiative. As a result, ethnic museums have blurred ideas on both their development prospects and work focus, unable either to further explore the breadth $\&$ depth of national cultural development, summarize historical experience to guide the development of national culture, or measure actual effect of public cultural service duties without realistic justifications. Ethnic museums need an unified design and long-term plan for future development, so as to clearly understand the general context and laws of museum undertaking development, actively construct ethnic cultural resource centers, promote the sharing of ethnic cultural heritage resources to protect the diversity of world culture.

Ethnic museums have no sufficient awareness and response to crises. Ethnic museums fail to dig deep into original ethnic culture, thus lack of expertise in existing research fields, therefore they face multiple challenges. Fine ethnic cultural relics by folk private collections have become specialized system and theme series, which is a negative shock to ethnic museums. Furthermore, comprehensive museums of humanities and history with complete systems, relying on their historical foundations and collection advantages, have long extended their tentacles to ethnic fields. They strive to surpass ethnic museums from funding and technical talents by holding various temporary ethnic exhibitions, permanent ethnic exhibitions or jointly building local ethnic museums, etc. Folk private and comprehensive museums have formed joint forces to squeeze the living space of ethnic museums and weaken the professional leadership and authority of ethnic museums. Ethnic museums have a general specialization, their professional capabilities obviously lag far behind folk private and comprehensive museums. They need to develop and improve their innovation capabilities and explore promising development space for the future in cooperation with the implementation of Belt and Road Initiative.

Ethnic museums of frontier areas lack sufficient financial support. Due to simple industries, backward technologies, underdeveloped economies in remote areas and limited local fiscal revenue, little funds allocate to cultural undertaking. Furthermore because of different affiliation systems, most ethnic museums fail to be covered by national free-admission special funds from cultural system or cultural relics system, unable to receive necessary funding support from national policies. Fund shortage leads to old-fashioned contents and methods of museum exhibitions, monotony of museum social education activities and few cultural and creative products, which greatly hinders museums to full play their display, education and service functions. It is difficult to stimulate ethnic museums' special roles in public education and culture service system, unable to meet growing cultural needs of audience along the Belt and Road Initiative. 


\section{Countermeasures of Ethnic Museums to Address the Problems Merged in The Belt and Road Initiative}

Ethnic museums should serve the top cultural strategy designed by the Belt and Road Initiative, actively cooperate with national public diplomacy and lead foreign cultural exchange activities. For the first time, museums' status set record high in the history, which creates an unprecedented situation to promote cultural and museum undertaking. Ethnic museums need completely change their understanding upon their positioning, responsibilities and functions, and elevate their work patterns \& thoughts. Museums are no longer previously basic social education facilities, but cultural undertaking of national strategy, changed from passive "preservatives and witnesses of past Chinese history" to proactive "witnesses and participants of contemporary Chinese history". The positioning change puts forward high standards and strict requirements to construct and develop the museums[9]. It is necessary to improve museums' professional capabilities through international exchanges and mutual understanding, actively participate in top cultural strategies of Belt and Road Initiative, and contribute to the progress of human civilization.

As palaces of national culture involving high-level international exchange activities, ethnic museums should dedicate to building a brand for China's foreign cultural exchanges, export outstanding values of China, establish a positive national image to world civilizations. There are multiple ways for ethnic museums to promote diversified cultural exchanges between China and neighboring countries in various fields, enhance mutual and tacit understanding and lay a solid foundation to implement the Belt and Road Initiative, such as jointly plan relics exhibitions of ethnic culture; launch museum technological and cultural product expos; hold ethnic regional museum forums to promote exchanges and cooperation of museum professionals; organize cultural heritage exhibitions \& cultural knowledge lectures; participate in cultural years, art festivals, cultural industry cooperation etc.

Ethnic museums should connect cultural institutions and groups along the Belt and Road Initiative, integrate the resources and strength of ethnic culture across regions from a professional perspective, and try to build international radiation centers of ethnic cultures. Ethnic museums are usually located in frontier ethnic provinces. They have rich ethnic cultural resources and location advantages of cultural diversity, which become nodes with geographical advantages and veritable cradles of ethnic cultures in the strategic plan of Belt and Road Initiative. Relying on existing resource and location advantages, museums in frontier ethnic regions need actively participate in the process of regional social development in an aim to become comprehensive and diversified international radiation centers for ethnic cultures through cultural exchanges to promote the circulation and utilization of cultural resources at home and abroad. Ethnic museums are able to efficiently integrate and innovate ethnic cultural resources of different countries and regions, break through national boundaries, fully play their geographic advantages and radiation effects, and improve the utilization efficiency and service radius of ethnic cultural facilities. They can enhance audience experience on ethnic cultural product in depth and breadth, create ethnic cultural facilities aggregation areas and international ethnic cultural experience areas, form influential ethnic cultural landmarks, and mobilize the vitality of ethnic culture and change the appearance of regional cultural development.

Ethnic museums, ethnic cultural palaces, ethnic cultural institutions, and ethnic cultural professionals of provinces, cities, counties, and districts in China can work together to form a multi-functional cultural complex, create a smooth communication platform for ethnic cultures and conduct professional exchanges between ethnic regions to promote their prosperity and growth. By analogizing their collections, ethnic museums should conduct in-depth research and conclude results, publish audio-visual products of different types of ethnic folk culture, and play their respective functions in complementary ways. It is necessary to establish a profound partnership among major ethnological museums, research institutions, professional societies, and industry associations, and jointly work for the world tangible and intangible cultural heritage of countries along the Belt and Road Initiative to protect historical and cultural heritage. Thus ethnic museums can deepen the methods $\&$ content of academic exchanges and build a bridge of communication among ethnic groups to protect and innovate ethnic cultural heritage through organizing academic conferences, museum forums, expert lectures, training course and ethnic cultural exhibitions.

Ethnic museums need deeply rooted in local ethnic communities to excavate, document and preserve historical and cultural resources with ethnic characteristics, and provide strong and profound cultural origin and cohesion for the Belt and Road Initiative. For high-quality ethnic cultural services, ethnic museums should develop unique cultural products with ethnic characteristics, meet diverse cultural needs of grassroots communities at different levels, fully play museums' function of social education, and promote gradual integration of Chinese culture into international mainstreams. Ethnic museums continuously work to strengthen the influence of Chinese culture and externally reshape Chinese culture confidence for a strong driving force to promote China's sustainable development and fulfill their cultural mission endowed by history.

To discover the essence of local ethnic culture, ethnic museums should break through the limitations of their physical buildings, start from communities and return back to communities, extend their professional tentacles to grassroots communities, fit the production and lifestyle of community residents, adopt unique ways to tell community stories and histories, design personalized community displays, highlight the participation and interaction of community members on the contents and design of museum exhibitions and education activities and reflect diverse characteristics of community ethnic cultures. Ethnic museums may establish regular community education bases, provide curriculum of general ethnic education, and unify community people's recognition on ethnic culture, and adopt multimedia technologies that community people like to show films and documentaries of ethnic culture and history to 
enrich the methods and contents of advocacy and education. Thus ethnic museums can disseminate ethnic cultural knowledge, eliminate cultural rifts between different nationalities, promote the integration of ethnic communities for the prosperity and development of ethnic community culture, turning themselves as a propellant leading high-quality ethnic cultural life of communities.

Ethnic museums should innovate their work model to enhance overall recognition on the Belt and Road Initiative among countries along the route. Countries along the Belt and Road Initiative have different languages, customs and values. Ethnic museums fully play their unique advantages in cultural kinship, explore the history and culture of neighboring nations and try to understand cultural differences of different countries, which can overcome the barriers between languages and cultures, promote the integration and consent among civilizations, achieve the cohesion of local and other cultures, and enhance widespread recognition and understanding on same values of the Belt and Road Initiative.

Ethnic museums may study cross-border ethnic groups originated from same roots. They are close to China geographically and culturally with compatible humanities, possessing diverse and inclusive ethnic culture. Based on respecting and maintaining characteristics of cross-border ethnic cultures, ethnic museums can prepare and create exhibitions with national ethnic characteristics for these ethnic groups, develop and design different cultural products and services, meet spiritual and cultural needs of countries along the route, and promote mutual respect and mutual understanding. On this basis, ethnic museums can promote in-depth cultural and economic cooperation, transform identities and behaviors of neighboring countries by participating in the Belt and Road: from "passive recipients" to "active participants", simply from "passiveness" to "proactiveness".

More important, ethnic museums need to focus on cultural nourishment for next generation and cultivation of national consciousness, provide children and young people of neighboring countries with opportunities to appreciate, understand and participate in management of tangible and intangible cultural heritage of various ethnic groups. Adopting modern technologies to keep pace with the time and network platforms to innovate exhibitions and education activities, ethnic museums may hold "online exhibitions" to attract more younger generation. Utilization of digital means in museum systems can improve ethnic cultural service supply system and maximize benefits of precious ethnic cultural relics. From academic and authority of museum perspectives, visitors can understand the stories behind ethnic cultural relics, experience cultural charm from diverse ethnic relics, appreciate the connotation and extension of ethnic cultural relics, enrich their spiritual and cultural life. Ethnic museums promote the exchange and understanding of Chinese and foreign civilizations, which enable outstanding ethnic cultural traditions to survive in the active consciousness of next generation.

COVID-19 epidemic dramatically transformed museums' conventional ways and fund allocation from physical display to online exhibitions, therefore optimized fund effectiveness to offset some fund shortage. During the epidemic, nearly $90 \%$ of world museums closed and over five thousands of Chinese museums shut down from January to May 2020, in order to avoid virus spread and cross-infection caused by population aggregation. Most museums canceled cultural exhibitions and failed to output creative cultural products. National Cultural Heritage Administration quickly instructed to: "encourage cultural relics museums/institutions to conduct online exhibitions in line with local conditions, encourage the utilization of existing cultural and museum digital resources to launch online exhibitions, and provide the public with safe and convenient online services."'[10] In a response, most museums immediately integrate existing digital resources, innovate communication methods, build cloud exhibitions and online museums through portals, mobile clients and WeChat applets etc. In total two hundred online cultural product projects were launched across the nation to meet people's spiritual and cultural needs, most of which were the results of digesting backlogs of funds and activities accumulated during the epidemic.

Under the circumstance of prevailing epidemic challenges, ethnic museums face new situations, new collection objects and new audiences in response to the theme of open cooperation by Belt and Road Initiative. Relying on unique advantages of abundant cultural resources, ethnic museums should break through traditions, transcend restrictions of time and space, play roles as dimensional cultural centers, adopt new methods to develop novelties, expand and provide creative exhibitions based on museums' collection and capabilities of research, exhibition and education, promote ethnic cultural exchanges and development at home and abroad to optimize cooperation implementation environment for the Belt and Road Initiative.

\section{Conclusion}

Silk Road initiated by Zhang Qian, a pioneer and outstanding diplomat, over 2,000 years ago, as an original commercial trade route for transporting silk from ancient China to Europe, has now become a Belt and Road Initiative, a way for China to rethink world's economic, cultural, and political structure. As ambassadors for cross-cultural exchanges and bridges for closer national relations, museums play increasingly important roles in today's international affairs. As important institutions carrying the history and culture of different nationalities, ethnic museums embody the unity of Chinese people. Their development is closely related to the development of ethnic groups and the state, responsible for historical missions of consolidating national identities, disseminating ethnic culture and enhancing cultural confidence.

Museum undertaking has now risen to a national strategy. At this new historical height, ethnic museums should continuously innovate concepts and models for exhibition display, exhibition education and exhibition advocacy, relying on their cultural resources \& scale, new geographical advantages and new audiences. Based on displaying unique culture of ethnic minorities, ethnic museums try to become a national business card to promote ethnic culture of China. To cooperate with the Belt and Road Initiative, ethnic museums 
should adopt modern technological means to become international radiation centers of ethnic culture. Civilizations and cultures of different countries will revitalize their charm in mutual radiance, creating welcoming international environment for the implementation of Belt and Road Initiative.

\section{References}

[1] Liu Yandong, Emphasized deep international cooperation to promote the prosperity and development of museums at the UNESCO High-Level Forum Museums, Xinhua News Agency, November 2016.

[2] Feng Jianyong, New Perspectives for China's Frontier Research of the Belt and Road Initiative [J], Xinjiang Journal of Normal University (Philosophy and Social Sciences Edition), January 2016.

[3] Exploring historical and cultural resources to serve the Belt and Road Strategy-Research Forum on the Construction of South Asia and Southeast Asia Cultural Radiation Center, Yunnan Academy of Social Sciences South and Southeast Asia Research Institute, May 2015.

[4] Data source: China's website of the Belt and Road Initiative, January 2021.

[5] Huang Lihua (translated), Building Sustainable Infrastructure to Support the Future Development of Cities, China Environmental Science, 2011.

[6] A statistical map of national museum-related statistics, China Fine Arts News, June 2020.

[7] Inner Mongolia, Guangxi, Chongqing, Sichuan, Guizhou, Yunnan, Tibet, Shaanxi, Gansu, Qinghai, Ningxia and Xinjiang.

[8] "Public Connections" of Ethnic Groups and Ethnic Regional Museums: Stepping into Life and Telling Cultural Stories, Economic Daily, November 2018.

[9] Leaders' speeches of Ministry of Culture and Tourism, State Administration of Cultural Heritage at the ethnic museums Work Symposium, February 2019.

[10] Notice on the Prevention and Control of the Covid-19, National Cultural Heritage Administration, January 2020 . 